\title{
The Role of Social Workers in Women's Personality Development Training
}

\author{
Fadilah Utami ${ }^{1 *}$, Iis Prasetyo ${ }^{2}$ \\ ${ }^{1,2)}$ Non Formal Education, Yogyakarta State University, Indonesia \\ *utamifadelah@gmail.com
}

\begin{abstract}
This study aims to determine and describe the role of social workers in the development of women's personality in the Mahabbah women's school program at the Muslimah Indonesia Foundation. The research method used descriptive qualitative. Research subjects were chairpersons, managers, and members as part of social workers. Data sources used were primary and secondary data sources. Data collection technique used literature study, observation and interviews and documentation. The results show that social workers have roles. First, the facilitator was shown by the interaction of Mahabbah women's school program participants in providing assistance, emotional support, and information in the learning process. Second, mediator provided mediation services in order to achieve the suitability of the objectives and welfare of participants. Third, counselor provided the guidance services to participants. Fourth, a group social adviser intervened follow-up meetings to discuss a developing topic. Social workers strived to make a high contribution to women's self-development through the Mahabbah women's school program
\end{abstract}

Keywords: social workers, women's empowerment

\section{Introduction}

Women are the most important part in world development. In the Islamic Encyclopedia, women in Arabic are called al-Mar'ah, plural of al-nissa' is equal to women or daughters, women are noble creatures, but many do not understand their role. Women as social beings also play role as children, wives, mothers, and $d a^{\prime} i$ (educators). Based on this notion, the role of social workers is needed in developing women's life skills so they can acknowledge their functions and compete and participate in developing the world. Social workers are people who contribute in certain areas of expertise and have authority in efforts to improve the ability of others to carry out their social functions as social beings through interaction; so people can develop themselves and adapt to life. The existence of social worker is likened to two hands that are constantly created to work together, which if not used for the good deed, it becomes evil.

Personality is a characteristic that stands out or appears to a person. As a person ages, it is expected that his skills will also improve. Abin Samyudin [1] describes aspects of personality that include character, temperament, attitude, emotional stability, responsibility and sociability. Character is related to the consequences of a person to obey behavior or ethics he adheres to, concerning consistency in principles, convictions or opinions. Temperament is the disposition reaction that comes from the environment in response to action, active or calm response to a particular style or characteristic of an individual. Attitude is a style that is presented in welcoming objects that can be positive, negative or ambivalent. Attitude is an 
individual's evaluation of an object or object. Emotional stability is the ability of individuals to react and process emotional stimuli, individuals who are able to understand what is felt and can express stimuli appropriately; those are individuals with good emotional stability. Responsibility is the conscious realization of the obligation. Where someone is willing to accept all risks from the actions that have been done. Sociability is a form of interpersonal individual in establishing social relationships with others which can be observed by the form of behavior that is open or closed to the social environment. Elizabet [2] suggests healthy personality characteristics, namely: being able to judge one's personality, knowing what strengths and weaknesses they possess either physically, skills, knowledge, and so forth. They can assess the real situation and accept the conditions naturally and do not require perfect conditions in all respects. They can assess the successes and achievements obtained in a realistic and rational manner, humble and stand out for achieving success, not reacting frontal, frustrated but with optimism to get better. Dare to accept responsibility, where individuals have confidence in the ability possessed to deal with life's problems traversed. Independence is the ability to take what is believed in decisions, develop themselves, direct, and adjust to the norms prevailing in their environment. Be independent in thinking and acting. Can control emotions, feel safe and comfortable with the emotions they have. Able to deal with situations that are depressed, forced, depressed, frustrated or stressed positively (constructively), not negative (destructive) or destructive. Have a goal oriented and formulate it in every life and activity by considering carefully and rationally, independently and not forced and can give efforts to the development of personality (insight), skills and knowledge they have. Socializing well oriented to the nature of respect, care, empathy for the situation and problems faced, think flexible, respect and respect for others, feel open and comfortable towards others, do not open up opportunities for others in negative things that can sacrifice him. Social acceptance where individuals can and are willing to actively participate in social activities and can be friends in establishing relationships with others. Having a philosophy of life that is based on the beliefs they hold. Happy; is a life situation that provides positive physical and mental pleasure and satisfaction supported by achievement, compassion, and acceptance.

Personality is something that refers to the behavior carried out by individuals (what an individual will do) [3]. Personality development is a skill and knowledge possessed by humans. Personality is influenced by the development of the era and lifestyle changes which require special skills related to changes in the personal person in dealing with it. It can also be said that personality is self-adjustment. Where individuals can provide a perceived response. Personality is everything that underlies attitudes, reaction patterns, habits, self-introduction, behavior, ways of thinking, ways of feeling, self-control, expressing yourself, exploring potential, motivating yourself, communicating, forming self-image, etc.), even how individuals are able to deal with critical, depressed situations. There is a special trait that can be learned and directed and applied by each individual that can be obtained and can be taken with training or education, special courses that train the development of personality, which relates to self-development (out) relating to appearance, posture, skills, etiquette, beauty, (inside) concerns attitudes of life, ways of thinking, personal, and so forth.

Anywhere, one of which is from course institutions or organizations engaged in humanity or society. In the process aims to hone, explore the potential, traits in a person and reduce bad traits in order to be realized more effectively and efficiently. In training that focuses on selfdevelopment, the individual will know himself better, he must know his abilities and limits. Understand the obstacles, reasons, and benefits of doing things and recognize them so that it can be interpreted as training can develop individuals more efficiently. Thus a person can understand and truly understand what and how the personality is, one must be able to accept 
and understand his personality first before trying to develop his personality, because the basic personality that has been formed from childhood and can not be changed. However, matters relating to needs, assessments and perceptions of something can continue to be developed and honed in accordance with needs. The era that continues to grow brings us humans to also help develop themselves and hone their expertise.

Abraham Maslow in the theory of hierarchy of needs states that each individual has certain wants and needs. Recognizing and understanding the most dominant needs will deliver and determine who the individual is. Every individual has a desire to achieve selfactualization, exploit potential and prove his existence in his environment. Women's ignorance of the roles, needs and personality that they must have will have a negative impact on their social lives. Its dual functioning has many impacts on the various lines of life that surround it.

To get the change in personality expected with a woman's character, a social worker who has the authority to provide learning and training is in accordance with the objectives of the women's empowerment program, this empowerment program is conceptualized as a school devoted to women aged 16 to unlimited who want knowledge more that is not obtained in formal schools.

The training carries the concept of adult learning which prioritizes experience as teaching material. The implementation of this training is planned so that students will get useful added value where they did not know to become know, and can develop knowledge gained in participating in the training. The training for women carried out by the Mahabbah Women's School is an effort to develop a comprehensive pattern of empowerment for the development of women in empowering them through an approach from the bottom up where the implementation in the field is carried out with the initiative and aspirations of women as learning citizens. In the concept of empowerment, the subject is human (self). The empowerment process emphasizes the process of providing abilities to the community to become more empowered, motivate and encourage individuals to have the ability and expertise or empowerment to make choices, and better their direction of life. It is said that empowerment must be aimed at groups or layers of society that are lagging behind or more specifically to those who need it according to analysts of social workers. In this case the social worker takes the direction of developing her community to women. It can be said that community empowerment is an effort to make people independent through the realization of the potential and abilities they have [4]. The context of empowerment in social work can be done through three approaches ranging from micro, mezzo, and macro.

Not much research related to alternative education for women highlights the development of women's personality, it still covers general factors that influence the social sphere such as Isti Larasati Widiastuty [5] that highlights the role of women and the educated population in an effort to achieve targets sustainable development goals in Indonesia. Therefore, the authors are interested in researching about personality development by social workers.

\section{Research Method}

In this study the authors used a qualitative approach with descriptive research methods. research with a qualitative approach will produce descriptive data in the form of written, oral words from the people who are the sources and observed behavior. Creswell [6] says that a qualitative approach aims to find and explore social or humanitarian problems. This is in line with the purpose of research in determining and analyzing in depth and detail the role of social workers in the development of women's personalities that can be explained with narration. To explain and discuss in detail the problems and realities in the field, a descriptive method was 
chosen that could explain the role of social workers in the development of women's personalities.

Research subjects are various parties who are directly involved in the process of empowering women, both students who are the objects of learning and social workers, where social workers have knowledge, can explain and express, state, demonstrate, demonstrate various activities related to the research focus. There were 5 informants consisting of 1 social worker and 4 students. The research site was conducted in Medan at the Indonesian Muslimah Foundation. Researchers chose this institution because there is a form of personal development training specifically for women.

\section{Results and Discussion}

Training is an effort made deliberately to give, add, complete one's knowledge in a particular field that can have a broad impact and can be used for the present and the future. Training provides additional skills to students, both those that can change in physical (spiritual) or non-physical (physical) aspects. Where the form of training is a form of empowerment that is centered on a particular subject that can be analyzed by the needs of social workers. There are many empowerment programs that are centered on individual selfdevelopment, for example manners, public speaking, counseling and so on, but there are forms of empowerment training that are unique and different from what is usually the empowerment of women's personalities. This empowerment training program has an impact on students. In this case social workers have a very significant role in providing new insights to students. Besides that social workers are not only facilitators but also play a role as facilitators, motivators, inspirators, moderators.

The analysis of social work not only includes consideration of the problems that arise but also considers in terms of the context of the needs and development of the process as social beings. Therefore, the beginning of social workers is the structure of needs and understanding of the existence of women's problems that entice social workers to participate in developing themselves as people who play a role in women's social problems.

The federal women's social institute (IFSW) says the social work profession sees the potential and weaknesses that are the basis of the changes to be achieved. In this case training to develop women's personality. This is focused on the needs of women to develop themselves as social creatures. Social Workers, according to Jorgensen and Hernandez, stated that there are several roles of social work in social coaching, including the role of facilitator who is often said to be an enabler, as an understanding that every change occurs originating from the existence of the client's own efforts and the role of social workers is to facilitate or allows the client to remedy the specified and mutually agreed upon settlement [7].

Social workers are areas of expertise possessed by someone who has the authority to make every effort to improve the ability of others to carry out their functions as social creatures and perform forms of social interaction so that they become good social people. In its approach, social workers carry out training on women's personality development using a micro, mezzo and macro approach. In its approach, social workers conduct training in the development of women's personalities with micro, mezzo and macro approaches $[7,8]$. In the Micro approach, training is carried out to clients in private individuals through guidance, counseling, stress management. This is done so as to guide and train the client in carrying out his main duties, both as a child, mother, or wife. In the micro approach social workers play a role from the beginning of the training until the training is finished and continues to the extent to which the trainees are able to maintain communication with social workers. In the Mezzo 
approach, training is conducted on a group of clients. This approach is carried out by utilizing groups as an intervention medium. Education and training, group dynamics are used as strategies to improve the ability of skills, awareness and knowledge and attitudes of clients to have the ability to solve the problems they face. Macro approach, this approach is a large system strategy approach (large system strategy), because the training target is directed at a broader system such as the environment and systems that move within the scope of the subject's life. This includes policy formulation, social action, social planning, community organization, conflict management which are used as strategies in the macro approach. In this approach the client is seen as someone who has the competence to understand the conditions they are experiencing and democratically choose and determine the right strategy in action.

Learning theory [9] states that there are 3 stages / stages of learning through which they include beginner (pre-instructional), learning (instructional), and assessment and follow-up (post) stages. The pre-instructional stage is the initial stage in starting learning where in this case the social worker as a facilitator digs up the information students have before the learning process begins. It starts by asking students' attendance, what is known about the material to be taught, asking about previous teaching material, giving students an opportunity about material that is not yet understood, repeating past teaching material briefly and covering all aspects previously discussed. This stage aims to reveal the students' responses to the material that has been received before and after receiving the material taught so as to provoke students to discover new problems and develop learning conditions that develop.

The instructional stages of the stages are focused on the activeness of students responding, processing, and transforming the material provided by social workers. Social workers as facilitators explain the learning objectives that must be achieved, write, discuss, make examples of the subject matter taught, use learning aids to clarify the discussion, and conclude the results of the discussion of all the subjects taught.

The stages of evaluation and follow-up are stages to determine the level of success of the second stage (the learning process). This activity includes the results that can be known by tests (assignments or homework), asking questions about all the subjects that have been discussed with students, if $70 \%$ of the questions asked to students are not able to answer means teaching materials have not been mastered correctly then workers social as a facilitator must repeat the material. The end of the lesson the social worker explains and tells the subject matter that will be discussed in a future lesson. The process and stages are concrete steps in the application of learning strategies which are also called learning activities.

In the initial process (pre-training) the recruitment and dissemination of information on training activities is carried out using social media, which targets are not limited to various groups and certain groups. Participants are charged a registration fee of Rp. 50,000 and learning commitment costs Rp. 200,000 (including kit, snacks, lunch, certificates) transferred to one of the social worker accounts. Those who have registered will be listed and included in the Mahabbah women's school list, which are grouped in specific batches according to the time of registration. Furthermore, the training process that has been determined and developed by presenters and social workers is adjusted to the experience of students, as well as the Quran and Hadith as a basis for learning. Social workers as facilitators and presenters prepare all training needs, both material, presentation slides, stationery and other training support matters. The training process which is grouped by batch is carried out in a conducive place which is adjusted to the number of participants which lasts for 2 days. The first day of training was divided into 4 sessions which lasted 6 hours. The first session of the material taught is about recognizing the purpose of creation, the second session is on the role of women as children, wife, mother and da'i (educators), session 3 is role optimization, the fourth or the last session 
is vision, life mission. In the process this training carries out transformational learning which is based on the experience of students directed by the speaker. Students are given the breadth of thinking and responding to the training materials provided so that students really understand and feel the learning atmosphere. In this session students usually express their grievances and expose the problems given and the speakers give their views and perceptions of a way out of the problems that students have. This learning is quite effective to see the enthusiasm and impact of the training material taught in accordance with the needs of students.

Final stage or (after training) students are expected to be able to clearly and structured describe their vision and mission after receiving training material for 2 days. From various testimonials there are 4 people as informants agree that this mahabbah women's school has successfully enlightened, opened and provided new facts and views about women that are not available elsewhere. From these 4 informants it can also be concluded that social workers play an important role in the various training processes that students go through, starting from pre, process and post training. The social worker is a facilitator, a companion. The absence of social workers will affect the success of the various training processes that are passed. This concludes the importance of social workers in participating in contributing to women's personality development training activities.

\section{Conclusion}

Conceptually, community empowerment carried out by social workers in the Mahabbah Women's School personality training seeks to improve the dignity and status of a woman who in the present condition is mixed with feminism understanding which obscures the view of women's nature as a gifted and special being. This empowerment emphasizes that people acquire skills, knowledge, and power that are able to influence themselves and others for the better.

Social workers have such an important role in various training processes for women's personality development. Social workers are professional work done by those who have a high social life on the issues that exist in the world that have the authority and a great opportunity to influence, change, shape, plan, and plan change.

Social workers in this case are involved in various professional activities that are very influential in the social service process. They play a role as facilitators, motivators, inspirators, and coordinators of the personality development training activities of mahabbah school women. In carrying out the task The social worker is able to define who is involved and the membership of the implementation of training activities, defines the purpose of involvement by encouraging intensive and relevant communication, as well as rewarding experiences and differences in client backgrounds, facilitating the quality and attachment and synergy quality of training products by finding common ground and differences, facilitating education by building skills and knowledge capabilities, becoming role models or examples and facilitating joint problem solving, encouraging collective activities by identifying problems and solving common problems, setting goals by designing alternative solutions and encouraging the implementation of tasks by maintaining system relations and solve conflicts. With this the role of social workers is formed into 4 dimensions, namely as defenders and protectors, brokers, and mediators [10] 


\section{References}

[1] Abin Syamsuddin. (2003), Tentang kepribadian. Yogyakarta : Rosda.

[2] Gunawan, S. (1999), Pembangunan Daerah dan Pemberdayaan Masyarakat. Jakarta: Bina Rena Pariwara.

[3] Ife, Jim. (2008), Alternatif Pengembangan Masyarakat di Era Globalisasi: Community Development. Yogyakarta: Pustaka Pelajar.

[4] Rulam Ahmadi. (2014), Pengantar Pendidikan. Yogyakarta : Az ruzz media.

[5] Yanti Muchtar.(2005), Pendidikan Alternatif untuk Perempuan. Jurnal Perempuan. Jakarta.

[6] Creswell, J. (2015), Riset Pendidikan. Yogyakarta: Pustaka Pelajar.

[7] Parsons, R. J., D, J. J., \& Hernandes, S. H. (1994), The Integration of Social Work Practice. California.

[8] Hatu, R. A. (2010), Pemberdayaan dan Pendampingan Sosial Dalam Masyarakat. Inovasi.

[9] Chusnul Chotimah,and M. Fathurrohman. (2018), Paradigma sistem pembelajaran. Yogyakarta : Az ruzz media. Federasi pekerja sosial internasional,

[10] Suharto, E. (2006), Membangun Masyarakat Membangun Rakyat. Kajian Strategis Pembangunan Sosial dan Pekerja Sosial. Bandung: Rafika Aditama. 